\title{
Review on the Response of Wheat (Triticum aestivum L.) Grain Yield to Different Planting Methods in Ethiopia
}

\author{
Tamirat Wato* $\quad$ Mekides Amare \\ College of Agriculture and Natural Resource, Department of Plant Science, Bonga University P.O. Box 334, \\ Bonga, Ethiopia
}

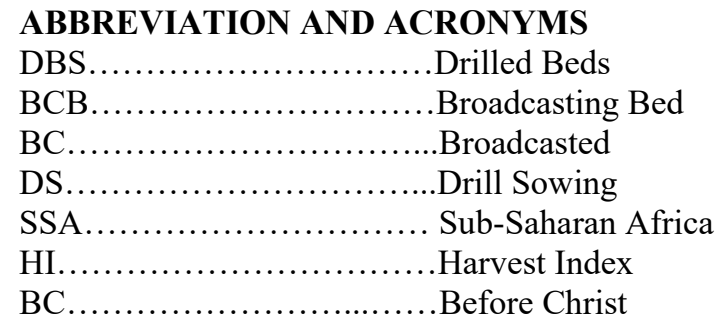

\begin{abstract}
Wheat (Triticum aestivum L.) is the grass family Poaceae (Gramineae) and it is the most significant source of carbohydrate. It is one of the first crops among cereals known to have been domesticated, and it is not only an important crop today; it also influenced human history. Wheat is the main factor enabling the emergence of citybased societies at the start of development because it was one of the first crops that could be easily cultivated on large scale, and had the additional advantage of yielding a harvest that provides long term storage of food. For increase wheat production management practices used by farmers vary greatly between locations and are influenced by a wide range of agro-climatic factors (temperature, rainfall, day length, soil type, and topography), biotic factors (pest and disease), and socioeconomic factors (cropping patterns, technology, and institutions. Wheat is grown in different types of farming systems and on many various scales. From those systems extensive farming systems which mean that cultivation of wheat under rain-fed areas and on large scale of land and intensive farming system indicate that cultivation wheat crop by using a different technology (by irrigation method) on small scale plot of land (less than one hector). From the above challenges, planting methods have a countless role in reducing wheat production. Planting methods being one of the most important agronomic factors plays an essential role in seed placement at an appropriate depth, ensure enhance seed emergence and succeeding crop growth. Thus, it is better to review the effects of different methods of wheat planting on production and productivity.
\end{abstract}

Keywords: Wheat, planting method and Grain yield of wheat

DOI: $10.7176 / \mathrm{FSQM} / 101-01$

Publication date:September $30^{\text {th }} 2020$

\section{INTRODUCTION}

Wheat is one of the most important cereal crops of the world and is a staple food for about one-third of the world's population (Hussain et al., 2002; Awoke et al., 2017). It is primarily used as a staple food providing more protein than any other cereal crop (Iqtidar et al., 2006; Bekele et al., 2014). In sub-Saharan Africa, Ethiopia ranks second to South Africa in terms of total wheat area and production (Awoke et al., 2017). In Ethiopia, wheat ranks fourth in total cultivated area and production (Tekle and Awoke, 2015).

According to Ephrem et al., (2000) and Awoke et al., (2017), Ethiopia is the largest wheat producer in SSA with the cultivated land of 1.1 million hectares. Area coverage of wheat increased from 600,000 to 760,000 ha between 1979/80 and 1994/95 CSA, (1989, 1995), Awoke et al., 2017). Despite the important area coverage of wheat production and productivity in the country, the average national yield $1.3 \mathrm{t} / \mathrm{ha}$ is $24 \%$ below the mean yield for Africa and 48\% below the global mean yield Bekele et al., (2000). Likewise, Hailu et al., (1992) reported that the national average yield of wheat is less than $1.5 \mathrm{t} \mathrm{ha}^{-1}$. Wheat is one of the world's three most important cereal crops (the other two are maize and rice) and it has the widest distribution of any cereal (Hassan, 2010). Among the food crops, wheat is one of the most abundant sources of energy and proteins for the world population and its increased production is Essential for food security (Chhokar et al., 2006). Ethiopia is second next to Egypt in Africa in wheat production which is 4.54 million tons in 2016 (CSA, 2017).

The selection of suitable sowing method plays an important role in the placement of seed at the proper depth, which ensures better emergence and subsequent crop growth (Sikander et al., 2003). Wheat is planted with different sowing methods depending upon the available soil water, time of planting, amount of residue in the field and availability of planting machine. Broadcasting not only requires a higher seed rate but also results in a lower plant population. Drill sowing is the recommended method because of its uniform seed distribution at the desired depth, which usually results in higher germination and uniform stands. Due to better crop stand establishment, 
wheat grain yield was significantly affected by the different sowing methods including broadcast and line sowing methods reported by (Sikander et al., 2003; Chhokar et al., 2017). According to Fenech and Pappy (1977), planting with the drill is superior to broadcasting if the seedbed is finely prepared. Therefore, the main objective of this paper is to review the effects of planting methods on yield and yield components of wheat.

\section{Origin and Distribution of Wheat}

The name wheat is used to describe several related wild and cultivated tritium species of which modern bread wheat (Triticum aestivum L), is the most widely cultivated today, followed by durum wheat, durum the center of origin of wheat is situated in an area of the near and middle east known as the fertile crescent, covering southern turkey, northern Iraq and adjacent regions of Iran and Syria (Emamu, 2018). Wild wheat still grows in the region today. Bread neither wheat nor durum wheat, both resulting from natural hybridizations among ancestral types, are found in the wild state (Emamu, 2018). Domestication of wheat, which directed to large-seeded and free threshing and winnowing wheat, took place between 17,000 and 12,000 BC. Wheat spread rapidly to North Africa, Asia, and Europe in prehistoric times, leavened bread originated in ancient Egypt (Emamu, 2018). The Spaniards introduced wheat into Mexico early in the $16^{\text {th }}$ century by the $19^{\text {th }}$ century it had spread all over North America. Early in the $20^{\text {th }}$ century, wheat was introduced into Kenya and eastern Congo-Kinshasa but was severely attacked by rust diseases. Eventually, it spread to other countries in eastern and southern Africa and was introduced into drier reigns of western Africa. Borlaug, (1970) the Nobel peace prize was awarded to a founder of the international maize and wheat improvement center in Mexico (Centro International de major amiento de maize Trigo, CIMMYT), for the development of high yielding semi-dwarf wheat for tropical regions, which resulted in dramatic yield increases, especially on the Indian sub-content(green revolution) (Raemackers, 2002; Imamu, 2018).

\subsection{Wheat Production in Ethiopia}

Ethiopia is the second-largest producer of wheat in Sub-Saharan Africa (Netsanet et al., 2017). Wheat is one of the major cereal crops in Ethiopia, which grows between 6 and $16^{\circ} \mathrm{N}$ latitudes; and between 35 and $42^{\circ} \mathrm{E}$ longitude ranging in altitude from $1500 \mathrm{~m}$ to $3000 \mathrm{~m}$ (CSA, 2010). It is largely grown in the highlands of the country and constitutes roughly $10 \%$ of the annual cereal production and plays an appreciable role in supplying the population with carbohydrate, protein, and mineral (Schulthess et al., 1997; Netsanet et al., 2017).

The major wheat-producing areas in Ethiopia are located in Arsi, Bale, Shewa, Ilubabor, Western Hareghe, Sidamo, Tigray, Northern Gonder and Gojam zones (Teklu and Hailemariam, 2009). Of the present total wheat production area, 75.5\% is found in Arsi, Bale, and Shewa regions. Forty-six percent of the 13 million ha classified as highly suitable for wheat production is found in Arsi and Shewa. Altitude plays a crucial role within the distribution of wheat production through its influence on rainfall, temperature, and diseases. In Arsi, Bale, and Shewa regions, the soil, moisture, and disease conditions within the $1900-2300 \mathrm{~m}$ altitude zone are favorable for the assembly of early and intermediate maturing varieties of bread wheat. This is estimated to comprise $25 \%$ of the total wheat area, while the remaining $75 \%$ falls in the $2300-2700 \mathrm{~m}$ altitude zone (Teklu and Hailemariam, 2009).

The main wheat-growing areas of Ethiopia are the high lands of the central, South Eastern and Northwest parts of the country. In terms of the regional contribution, the assembly of wheat originates from Oromia (57.4\%), Amhara (27\%), SNNP (8.7\%) and Tigray (6.2\%) and quite $41 \%$ of the annual wheat production comes from only three-zone in Oromia and one in Amara regions (CSA, 2015-2016).

\subsection{Importance of Wheat}

Wheat contributes more calories and protein to the world diet than any other cereal crops (Shewry, 2009; Hyacinthe et al., 2018). According to Kandel et al., and Hyacinthe et al., (2018) reported that it is nutritious, easy to store and transport and can be processed into various types of food. Wheat is taken into account an honest source of protein, minerals, B- group vitamins and dietary fiber (Simmonds, 1989; Shewry, 2007; Yahia, 2015), although environmental conditions can affect the nutritional composition of wheat grains with its essential coating of bran, vitamins, and minerals; it's excellent health-building food. Wheat is also used as animal feed, for ethanol production, wheat-based raw material cosmetics, wheat protein in a meat substitute and to make wheat straw composites. Wheat germ and wheat bran can be a good source of dietary fiber helps in the prevention and treatment of some digestive disorders (Simmonds,1989; Yahia, 2015). Wheat contains carbohydrate 78.1\%, and protein $14.7 \%$, fat $2.1 \%$ minerals $2.1 \%$ and considerable of vitamins (thiamine and vitamin B) (Yahia, 2015). Most commercially cultivated wheat comes in two basic types that vary in genetic complexity, adaptation, and importance (Lantican et al., 2005); durum and bread wheat. Durum wheat derived from the fusion of to grasses species the same 10000 years ago, while bread wheat was derived from a cross between durum wheat and third grass species about 800 years ago (Yahia, 2015).

Now a day, bread and durum are accustomed to making a variety of widely consumed food products. Shewry (2007) also reported that it is nutritious, easy to store and transport and can be processed into various types of food. 
In Ethiopia, wheat grain is used in the preparation range of traditional food products such as injera, fermented bread, porridge ("genfo"), roasted grain ("kolo"), local fermented beer ("tella"), distilled local sprit ("areki") and other local food items (Najafi et al., 2014). Wheat is a primary source of carolers and protein for 4.5 billion peoples is more than 100 countries (Sanjaya, 2014).

\subsection{Wheat Sowing Methods}

The most outdated method of sowing wheat is just walking an organized field throwing out seed as you go. In fact, it is an extremely skilled job to get even coverage and even when done well usually much seed is lost to birds and if weeds become a problem, they cannot be hoed out. For broadcast sowing, very poor establishment percentage is common, often falling below 50 percent (Emamu, 2018). For germination to occur in seeds there is the need for row seedbed to be in perfect contact with the soil to facilitate water uptake (Oyewole et al, 2010; Emamu, 2018). The broadcasting system with poor quality of seed, poor soil fertility and seed rate, which is $125-175 \mathrm{~kg} / \mathrm{ha}$, which makes the mature plant lodge i.e. fall over. This whole thing influenced the population of wheat. Another consideration of higher plant stand is a thicker canopy which may lead to higher disease pressure, scouting was important during the season to monitor disease pressure in case fungicide applications are warranted (Oyewoleet, 2010).

As applied in convocational horizontal farming or gardening is a system of growing crops in drilling (row) pattern in at least one direction rather than sowing without any distinction and arrangement. It is practiced in most crops whether direct seedbed, transplanted or grown from vegetative planting material both in mono-cropping and multiple cropping (Bareja, 2011). Crops are planted in drilling mostly to increase yields and for convincing. The restriction to drill sowing wheat by hand in Ethiopia is that the high labor and time requirement. Dibbling was used historically when the seed of wheat was scarce or when a farmer wanted to bulk up a limited or new but small seed supply as fast as possible. The appropriate depth and spaced holes were made by the farmer with a dibbler and therefore the farmers put two or three seeds in each hole. The method lends itself to a school situation as individual children either singly or in groups can take responsibility for sowing in individual holes. However, manual drilling and dibbling seeding are extremely labored intensive and unacceptable to peasant farmers in Ethiopia (Assefa et al., 2005; Emamu, 2018).

\subsection{Germination and Seedling Growth}

Environmental factors play a great role in seed germination and seedling growth in plants. During the planting of wheat to germinate, the seed requires an adequate condition like temperature and moisture. Wheat seeds germinate at temperatures of $39^{\circ} \mathrm{F}$ or higher; temperatures between $54^{\circ}$ and $77^{\circ} \mathrm{F}$ are considered optimum for rapid germination and growth (Emamu, 2018). Germination starts when the seed absorbs water from the soil and reaches 35 to $45 \%$ moisture on a dry weight basis. During germination, the seedling (seminal) roots, include primary root (radical), emerge from the seed along with the coleoptiles (leaf-like structure), which encloses the primary leaves and protects the first true leaf during emergence from the soil (Bareja, 2011). Under promising conditions, the emergence of seedling happens within a week. Until the first leaf becomes functional, the seedling depends on energy and nutrients stored in the seed. Seedling growth begins with the emergence of the first leaf above the soil surface and continues until the next stage, tillering (Biranu, 1986).

Normally three or more leaves develop in the seedling stage before tillering was initiated (Abdus et al., 2016). Each new leaf can be counted when it is over one-half of the length of the older leaf below it. During this stage, the fibrous root system grows more entirely, serving Crops/plant establishment. The crown (a region of lower nodes whose internodes do not elongate) is located between the seed and the soil surface (Emamu, 2018). It tends to develop at an equivalent level, about one-half to at least one inch below the soil surface, regardless of planting depth. Leaves, tillers, and roots (including the main root system) develop from the crown nodes (Abbas et al., 2009).

\subsection{Tillering}

Tillers are lateral branches or shoots that arise from buds in the axils of the leaves at the base of the main stem (Abdus Subdan et al., 2016). Primary tillers are produced from the leaves of the most stem and may form their own secondary tillers. The tillering stage begins with the emergence of lateral shoots (tillers) from the axils of truth leaves at the bottom of the most stem of the plant (Oyewole, 2010). The number of tillers produced from the secondary buds positioned at each crown node. Primary tillers form in the axils of the first four or more true leaves of the main stem (Emamu, 2018). Secondary tillers may develop from the bottom of primary tillers if conditions favor tiller development. A tiller may also develop from the coleoptile node (coleoptile tiller), but this occurs sporadically and its appearance is dependent on genotype, sowing practices, and environmental conditions (Biranu, 1986, Emamu, 2018).

At the base of each tiller is a sheath (small leaf-like structure) called the prophyll, from which the tiller leaves emerge (Bareja, 2011). Identifying the prophyll, which encloses the base of the tiller help differentiate tiller leaves 
from the leaves on the main stem and from other tillers. Tillering usually begins when the seedling plant has three or more fully developed leaves. Tillers depend on the main stem for nutrition during their development (Abbas et al., 2009). Once a tiller has developed three or more leaves, it becomes nutritionally independent of the most stem and forms its own rootage. Tillers are a crucial component of wheat yield because they need the potential to develop grain-bearing heads. In Ethiopia, each plant normally develops two or more tillers within the fall when planted at optimum dates. The total number of effective tillers finally developed not altogether produce grainbearing heads. Under recommended plant populations, usually two or three tillers, in addition to the main shoot, produce grain (Abbas et al., 2001; Emamu, 2018).

\subsection{Stem Elongation}

Growth is the product of the elongation of the internodes. The crown consists of eight to 14 nodes stacked closely above one another, separated by internodes less than $1 \mathrm{~mm}$ long (Tesfaye, 2016). Lower internodes remain compressed at the base, with the number depending on the sowing rate and variety (Schulthess, 1999). Internodes begin to elongate when the leaf associated with it reaches full size (Emamu, 2018). When these internodes are half the final length the one above it begins to grow, and this continues until the last internodes (the peduncle, which carries the head) is fully elongated and the stem is at its final length (Reddy and Fageria, 2002; Emamu, 2018). Each internode is longer than the last so that the peduncle is the longest of all. Overhead the node is the distended leaf base, which has a significant role if lodging happens. If the crop is laid flat, the stems turn upwards and, in response to gravity, the side nearest to the ground grows at a faster rate than the side facing upwards. This causes the swollen leaf base to become uneven, turning the stem and head upwards. Nodes are where structures such as leaves, roots, tillers, and spikelets join the stem (Seyfu, 1997; Emamu, 2018). The internodes are the tissue between adjacent nodes that elongates because the stem grows. The stem is wrapped within the sheaths of the encompassing leaves. This structure of stem and leaves gives strength to the shoot, helping to keep the plant upright (Kahn et al., 2007). Because the stem grows, it changes function from providing support for plant leaves to storing carbohydrates and different nutrients for the grain filling stage.

\subsection{Effects of Planting Method on Growth Parameters of wheat}

\subsubsection{Effects of different sowing methods on leaf area}

The area of the leaf of plants was highly influenced by different planting techniques from those in Broadcast, Drilling and Dibbling sowing methods have more a significance difference (Emamu, 2018). Though, the professed difference was similar in drilling and dibbling excluding the last mean at broadcasting sowing methods.

\subsubsection{Effects of planting method on leaf length}

The leaf length was dependent on sowing methods and other factors (Emamu, 2018). Based on the results of the current analysis the length of the leaf under the different planting methods has a more significant difference. Leaf length highly influenced by broadcasting planting methods (Table1). However, the declared difference was lower mean in broadcasting methods and the same except numerical difference under both dibbling and drilling sowing methods (Sinkader, 2003).

\subsubsection{Effects of planting method on leaf number}

The leaf number is a factor of photosynthesis in green plants and it is one of the essential parts of the plant (Abbas et al., 2005). Leaf numbers in different sowing methods were significantly different in broadcasting, drilling and dibbling sowing methods (Table1). However, the highest mean values were under drilling sowing methods and both sowing methods were statistically the same (Emamu, 2018).

Table 1. Effects of different planting methods on leaf area, leaf length and Numbers of the leaf

\begin{tabular}{|c|c|c|c|}
\hline & Sowing method & Mean + SE & P-Value \\
\hline Variable & Broadcasting & $4.275+0.056$ & 0.0306 \\
\cline { 2 - 4 } & Drilling & $4.47+0.056$ & \\
\cline { 2 - 4 } & Dibbling & $4.15+0.056$ & 0.0002 \\
\hline \multirow{3}{*}{ Leaf length } & Broadcasting & $12.745+0.149$ & \\
\cline { 2 - 4 } & Drilling & $14.918+0.149$ & 0.0004 \\
\cline { 2 - 4 } & Dibbling & $13.798+0.149$ & \\
\hline \multirow{3}{*}{ No of leaf } & Broadcasting & $3.5+0.167$ & \\
\cline { 2 - 4 } & Drilling & $4.5+0.167$ & \\
\cline { 2 - 4 } & Dibbling & $4+0.167$ & \\
\hline
\end{tabular}

Source: Emamu, 2018

\subsection{Effects of Planting Method on Yield and Yield Components of Wheat}

Planting method has a significant effect on water, nitrogen and phosphorus economy, energy savings and soil compaction (Trodson et al., 1989; Attaullah, et al., 2007). Absorption of photosynthetically active radiations has 
also been found to be influenced by planting methods (Lal et al., 1991; Mishra and Tiwari, 1999). Khan et al., (2007) have reported that lower root weight in the broadcast method as compared to non-conventional planting methods. Furthermore, weed density is also higher in conventional planting methods as compared to the nontraditional methods e.g. cross planting. This causes a significant effect on ultimate crop growth and thus on grain yield.

Row planting and placement of fertilizers in rows have shown maximum yield than broadcasting (Mishra and Tiwari, 1999). This may make an important influence on crop growth and thus on grain yield. Hassan and Hassan (1994) have shown that wheat planted in furrows gives maximum 1000- grain weight, straw yield, and grain yield. Sikander et al., (2003) reported that the plant density, ears $\mathrm{m}^{-2}$, number of grains per ear, 1000-grain weight and grain yield were higher in drill planted wheat than broadcasted wheat (Table 2). Higher wheat grain yields with drill planting as compared to broadcast (Kipps, 1970). Dawelbeit and Babiker (1997) have reported maximum yield for seed drilling and ridging after broadcasting than broadcasting alone. Row Planting and placement of fertilizers in rows have shown maximum yield than broadcasting (Mishra and Tiwari, 1999). The planting method was recognized significant on yield and yield contributing characters of wheat.

Planting methods had a significant effect on the emergence of wheat (Sikander, 2003). The highest number of wheat plants emerged with the drill sowing method which followed by broadcasted beds. On the other hand, wheat emergence was poor with broadcasting and drilled bed methods. Higher emergence with drill sowing could be due to sowing at optimum sowing depth, whereas the bed formation after broadcasting could have resulted in the placement of seed deeper (Dawinkele 1997; Sikander, 2003). Poor wheat emergence in broadcasting as compared to drill sowing was also reported by Shaalan et al., 1997; Sikander, 2003. At harvesting number of heads, $\mathrm{m}^{-2}$ was higher with BCB and DSB as compared to broadcasting and drill sowing method (Sinkader, 2003). The biological yield was significantly higher in flat planted wheat (broadcasting and drill sow) (Sikander et al., (2003) (Fig. 1). Despite the reducing number of heads $\mathrm{m}^{2}$ in broadcasting and drill sowing methods than BCB and DSB planting methods, the upper biological yield in flat planted wheat might be attributed to more infertile tillers and vegetative growth. There were no significant differences in the biological yield of drill sown and broadcasted wheat (Sikander, 2003) (Fig. 1). Although the number of heads $\mathrm{m}^{-2}$, spike length and a number of grains per spike were significantly higher in raised bed wheat (broadcasted and drill sown) in comparison with bed planted wheat (BCB and DSB) (Darwinkle, 1977; Sinkander et al., 2003) (Table 2).

Despite the lower number of heads $\mathrm{m}^{-2}$ in broadcasting and drill sowing methods than BCB and DSB planting methods, the higher biological yield in flat planted wheat could be attributed to more infertile tillers and vegetative growth (Sinkander et al., 2003). Harvest index was significantly higher in wheat planted on raised beds in comparison with the broadcasted and drill sowed wheat, which indicated better water use efficiency in terms of grain production. Because of seed placement at the proper depth, the drill sowing method resulted in better emergence than other planting methods. Better crop establishment in drill sown wheat resulted in a higher grain and biological yield of wheat in comparison with other planting methods. Despite the higher number of heads $\mathrm{m}^{-}$ ${ }^{2}$, spike length and the number of grains per spike in raised bed wheat (broadcasted and drilled beds), the wheat grain yields were minimum in raised bed wheat than flat sown wheat (Sikander et al., 2003). Wheat on raised bed met the tricky of emergence, which caused its yield ultimately. The problem of crop stand establishment in raised beds could be overcome with the availability of proper bed planting machines, which should form beds and place the seed at the proper depth. With the establishment of an ideal crop stand, improved yield can be attained with this technique.

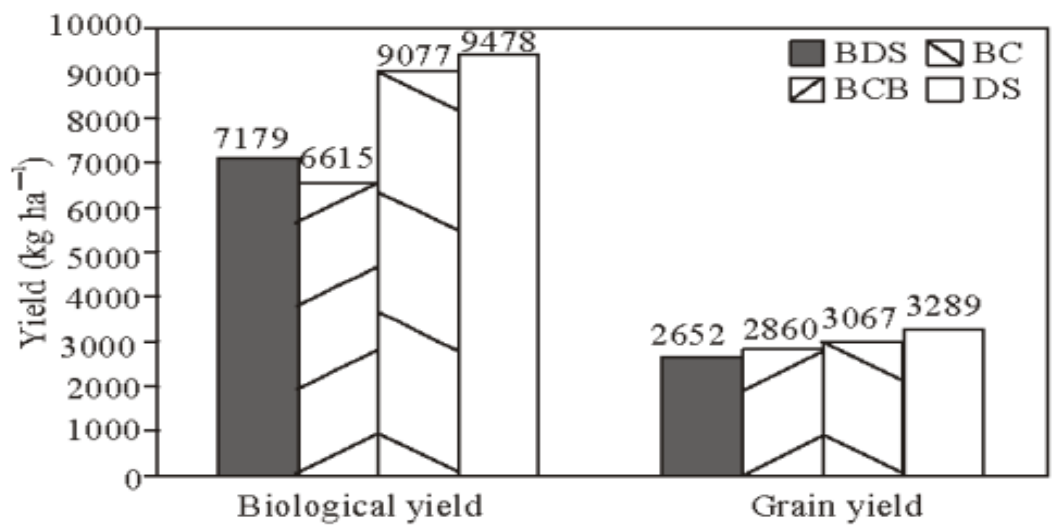

Fig 1. Effects of Different Planting Methods in Grain yield of Wheat 
Table 2: Wheat performance under different planting methods

\begin{tabular}{|l|c|c|c|c|c|c|c|}
\hline Sowing Method & $\mathrm{E}\left(\mathrm{m}^{-2)}\right.$ & $\mathrm{H}\left(\mathrm{m}^{-2)}\right.$ & $\mathrm{PH}(\mathrm{cm})$ & $\mathrm{SL}(\mathrm{cm})$ & $\mathrm{G} / \mathrm{S}$ & $\begin{array}{c}1000 \mathrm{GW} \\
(\mathrm{gm})\end{array}$ & H.I (\%) \\
\hline Drilled Beds (DBS) & $130^{\mathrm{c}}$ & $259^{\mathrm{a}}$ & $86.11^{\mathrm{ab}}$ & $9.90^{\mathrm{a}}$ & $55.7^{\mathrm{a}}$ & $43.5^{\mathrm{b}}$ & $37.1^{\mathrm{b}}$ \\
\hline Broadcast Bed (BCB) & $146^{\mathrm{b}}$ & $278^{\mathrm{a}}$ & $84.11^{\mathrm{b}}$ & $9.40^{\mathrm{b}}$ & $52.9^{\mathrm{b}}$ & $43.5^{\mathrm{b}}$ & $43.8^{\mathrm{a}}$ \\
\hline Broad casting (BC) & $129^{\mathrm{c}}$ & $200^{\mathrm{b}}$ & $85.90^{\mathrm{ab}}$ & $9.20^{\mathrm{b}}$ & $50.0^{\mathrm{c}}$ & $46.3^{\mathrm{a}}$ & $33.8^{\mathrm{c}}$ \\
\hline Drill Sowing (DS) & $182^{\mathrm{a}}$ & $212^{\mathrm{b}}$ & $88.78^{\mathrm{a}}$ & $9.30^{\mathrm{b}}$ & $50.1^{\mathrm{c}}$ & $46.6^{\mathrm{a}}$ & $34.7^{\mathrm{b}}$ \\
\hline
\end{tabular}

E: Emergence, H: Heads, PH: Plant Height, SL: Spike Length, Grain per spike, GW: Grain Weight, HI: Harvest Index

Source: Sikander et al., 2003

\section{SUMMARY AND CONCLUSION}

Wheat (Triticum aestivum L.) is the grass family Poaceae (Gramineae) genus of Triticum. It is one of the most important cereal crops which is highly produced throughout the world. Wheat is originated in far east country especially Asian countries. It is an exotic cereal crop for Ethiopia. Its production is more common in the central high land, northeastern and southwestern parts Ethiopian country, however, there are different constraints which are causing the loose of wheat production. Planting methods are able to influence the growth, development and also on yield and component of wheat. If it's not properly applied it has effects on different parts of plants like a seedling of emergence, elongation of the stem, leaf area, leaf number, root elongations, number of spike and grain yields of wheat. Planting methods in broadcasting, drilling, and dibbling sowing methods have a more significant difference in most of the growth parameters. This indicates that the drilling planting method has able a good leaf length. Biological yield is more depends on the planting method because yields and parameters of the wheat crop have direct relationships. If parameters of wheat are damaged, it has effects on the final maximum yield of production is become reduced. Different planting methods had a significant effect on yield and yield components of wheat. Thus, the drill method of planting is a better way to maximize the productivity of wheat. Finally, rather than using the traditional (broadcasting) methods of planting, row/drill planting wheat increases production and productivity in Ethiopia.

\section{KEY GAPS RECOGNIZED RELATED TO THE PRODUCTION OF CROPS AND USES OF NEW TECHNOLOGIES}

Even if there is a good start in the production and uses new technologies of agricultural production in Ethiopia as food for maintaining food security and to alleviate poverty, as a source of income for the foreign currency, a lot remains to be done to exploit the full potential of crop production. In this respect, some important challenges on production and uses of new technologies were identified and listed below:

- Lack of awareness among potential producers about better agronomic practices and technology

- Insufficient work on research and dissemination of information about technology in different agroecologies of the country.

- Inadequate training activities on the better agronomic practices and uses of technology

- Among rural farmers, illiteracy, insufficient extension service, etc were found to be barriers to the adoption of technologies.

- Insufficient linkage and collaboration among stakeholders on technology.

\section{RECOMMENDATIONS}

Therefore, in order to effectively and efficiently bond these gaps in agricultural production and productivity in Ethiopia for the new technology, the following key points are recommended:

* Awareness creation among the producers through various pathways including training, media, and field demonstration, etc on the importance of improved technologies, best agronomic practices as alternative or supplementary means of increasing production and maintaining food security is recommended.

* More research work on agronomic practices, crop protection, crop production, and soil fertility is needed.

* Intensive training on new technologies to farmers is vital.

* Positive reinforcement and incentives are needed to attract more and more private/investors and public sectors to involve in commercial production of new technologies like different fertilizers.

* All of the above targets can only be achieved however when all stakeholders (private, Governmental and Non-governmental Organization, public, NGO, Academia, Ministery of Agriculture, etc.) come together and collaborate with each other and contribute to ways and methods of agronomic practices and technologies. 


\section{REFERENCES}

A Hyacinthe, F. J. Bedel, E. E. S. Gbocho, Y. J. Constant, K. L. Patrice. (2018). Chemical Composition and Nutritional Value of Composite Wheat Flours (Triticum aestivum) and Two Varieties of Taro Corms (Colocasia esculenta) Cultivar Fouê And Cultivar Yatan. IOSR Journal of Environmental Science, Toxicology and Food Technology (IOSR-JESTFT): V12 (8); PP 24-28. www.iosrjournals.org

Abdus-Subhan, Q. Khan, M. Mansoor, M. J. Khan, Amanullah, M. Khan. (2016). The response of Wheat to Tillage and Sowing Techniques under Arid Condition.

Adams ML, Lombi E, Zhao FJ. (2002). Evidence of low selenium concentration in UK bread-making wheat grain. Journal of the science of Food and Agriculture, 82:1160-1165.

Assefa A. (2005). Farm management in the mixed crop-livestock system in the Northern Attaullha Khan.

Attaullah Khan, Attaullah Khan, Muhammad Arif, Asad Shah, Sajid Ali, Zahira Hussain, and Sajjad Khan. (2007). Evaluation of Planting Methods for Grain Yield and Yield Components of Wheat. Sarhad J. Agric. Vol. 23, No. 3 561-563

Awoke Tadesse, Tekle Yoseph, and Misgana Mitiku. (2017). "Effect of Sowing Methods and Seed Rate on Yield of Bread Wheat (Triticum Aestivum L.) At South Ari District, South Omo Zone, SNNPR, Ethiopia. International Journal of Research - Granthaalayah, 5(6), 175-180. https://doi.org/10.5281/zenodo.818814.

B. Bareja. (2011). The nature and properties of soil $13^{\text {th }}$ ed. person education Ltd., USA.2

Bekele H., Kotu H, Verkuijl, W. Mwangi and D. Tanner. (2000). Adoption of Improved Wheat Technologies in Adaba and Dodola Woredas of the Bale Highlands, Ethiopia. Mexico, D.F.: International Maize and Wheat Improvement Center (CIMMYT) and Ethiopian Agricultural Research Organization (EARO).

Bekele, Mideksa, and Tadele Shiberu. (2014). "Adoption of Improved Bread Wheat Varieties on Small-Scale Farmers: The Case of Boji Gebisa Ambo District, Oromia Regional State, Ethiopia." American Journal of Food Science and Technology; 2 (3): 103-108.

Berhanu K. (1986). A review of weed control research activities on teff in Ethiopia. pp.149-159. In a review of crop protection research in Ethiopia. proceeding of the first Ethiopian crop Changing World, Challenges and Achievements, CIMMYT, D.F, Mexico Changing World, Challenges and Achievements, CIMMYT, D.F, Mexico.

Central Statistics Authority (CSA). (1989). Time series data on area, production, and yield of major crops: 1979/80-1985/86. Statistical Bulletin 56. Addis Ababa, Ethiopia.

Central Statistics Authority (CSA). (1995). Agricultural sample survey (1994/95): Report on area and production for major crops for private peasant holding, main season. Statistical Bulletin 132. Addis Ababa, Ethiopia: CSA.

Chhokar RS, RK Sharma, SC Gill, and R Kumar. (2017). Influence of tillage, cultivar, seed rate and planting geometry on wheat yield. Journal of Wheat Research 9(1): 12-20. doi.org/10.25174/2249-4065/2017/71641

Central Statistical Agency (CSA). (2010). Agricultural sample survey 2009/10. Report on area production of crops (private Peasant holdings, Meher season). Stat. Bullet. 466, Addis Ababa

Darwinkle A. (1977). Sowing methods and grain yield of winter wheat. Bedrijfs on twinkling (NL), 8;709-712.

Dawelbeit, M. I and E.A, Babiker. (1997). Effect of tillage and method of planting on wheat yield in irrigated Vertisols of Rahad, Sudan. Soil and Tillage Res.42. (1-2):127- 132

Desai, R.M and B. S Trevadi. (1991). Nitrogen utilization by wheat varieties grown on vertisols with different sowing methods. Gujarat Agril Univ. Res, j. 17:106-109.

Duncan D.B. (1955). Multiple ranges and multiple F tests. Biometrics, 11:1.

Emamu Sh. (2018). Effect of Sowing Methods on Wheat (Triticum aestivum L.) Growth under the condition of Jimma.

Ephrem B., H. Kebede, and G. Belay. (2000). Wheat in Ethiopia: An old crop in an ancient land. Institute of Biodiversity Conservation (IBCR), Addis Ababa, Ethiopia.

G. Abbas, M. A. Ali, G. Abbas, M. Azam, and I. Hussain. (2009). Impact of Planting Methods on Wheat Grain Yield and Yield Contributing Parameters. The Journal of Animal \& Plant Sciences: 19(1), 30-33 http://www.fao.org/faostat (cited 24 Feb. 2005; verified 14 Oct. 2005).

Gowayed S. (2009). Egyptian wheat. Doctoral Dissertation. Department of Agrobiodiversity, institute of crop science, University of Kassel, Germany.

Hailu B. and Chilot Y. (1992). An adoption study of bread wheat technologies in Wolmera and Addis Alem areas of Ethiopia. In: D.G. Tanner, and W. Mwangi (eds.), Seven ${ }^{\text {th }}$ Regional Wheat Workshop for Eastern.

Hasan K. (2010). The effect of planting methods on yield and yield components of irrigated spring durum wheat varieties. Scientific Research and Essays; Vol. 5(20), pp. 3063-3069,

Hassan, K. H, and F. Hassan. (1994). The response of some wheat cultivars to planting methods under saline irrigation water. Annals-of-Agricultural-Science-Cairo. 39(1): 167-176.

Hobbs, P.R. Sayare and J.J Ortiz Monasterio. (1998). Increasing wheat yield sustainability through agronomic 
means. NR. Gppapper 98-01. Mexico, D.F, CIMMYT. PP 22.

Hussain MI. and SH. Shah. (2002). Growth, yield and quality response of three wheat (Triticum aestivum L.) varieties to different levels of N, P and K. Int. J.of Agri. and Bio. 4(3): 362-364.

Iqtidar H, Muhammad AK, and AK Ejaz. (2006). Bread wheat varieties as influenced by different nitrogen levels. J. Zhejiang Univ. Sci. 7(1): 70-78.

Kipps, M. S. (1970). Production of field crops. $6^{\text {th }}$ eds. McGraw Hill Book Co. New York.

Lal, J., V.U.M, Rao and O. P, Bishnoi. (1991). Radiation climate of the wheat crop as affected by the method of planting. Haryana Agric. Univ. J. Res. 21 (4): 280-286.

Lantican, M.A., Dubin, H.J., Morris, M.L. (2005). Impacts of international wheat breeding research in the developing world, 1989-2002. Wheat breeding environment.

M. Arif. Asadshah. S. Ali, Z. Hussian and S. Khan. (2007). Evaluation of planting methods for grain yield and yield components of wheat: Sarhad J. Agric. vol. 23, no.3, 2007.

M. Kandel, A. Bastola, P. Sapkota, O. Chaudhary, P. Dhakal, P. Chalise, J. Shrestha. (2018). Analysis of Genetic Diversity among the Different Wheat (Triticum aestivum L.) Genotypes. Turkish Journal of Agricultural and Natural Sciences. DOI: 10.30910/turkjans.421363

Mishra, M. K. J and R. C, Tiwari. (1999). Effect of seeding methods and fertilizer application on weed biomass and yield of wheat (Triticum aestivum L.). Indian J. Agron. 44(2): 353-356.

Najafi, A. (2014). Wheat production price-performance prediction in Iranian north provenance African journal Agriculture Research, 9(1), 74-79.

Netsanet H., Hussein A. Sh. and M. Laing. (2017). Appraisal of farmers' wheat production constraints and breeding priorities in rust-prone agro-ecologies of Ethiopia. African Journal of Agricultural Research: Vol. 12(12), pp. 944-952, 23. DOI: 10.5897/AJAR2016.11518.

Fageria NR, and H.R Ghe. (2003). Plant tissue test for determination and uptake of Nitrogen and Phosphorus different growth stage in low and rice community in soil science and plant analysis 34:259-270).

Sanjaya. R. (2015). The world food prize, global and regional food consumption patterns, and trends.

Schulthess U., B. Feil, and S.C. Jutzi. (1997). Yield independent variation in grain nitrogen and Phosphorus concentration among Ethiopian wheat. Agronomy Journal. 89 (3): 497-506

Seyfu K. (1997). Teff (Eragrostis tef (zucc.) Trotter). Promoting the conservation and use of underutilizing and neglected crops, 12. Institute of plant genetics and crops plant research, Gaterisebenl international plant genetic resources institute, Rome Italy. Statistical Bulletin 388.Addis Ababa, Ethiopia.

Shaalan, M. I, M.S. Chaudary and F.A Sorour. (1977). The effects of tillage and planting methods on growths weed population and yield of semi-dwarf wheat. Libyan. Agric 6:55-67

Shewry PR. (2007). Improving the protein content and composition of cereal grain. Journal of cereal science, 46:239-250.

Sikander K. Tnaveer, Imtiaz Hussain, M. Sohail, N.S. Kissan and S.G. Abbas. (2003). Effects of Different Planting Methods on Yield and Yield Components of Wheat. Asian Journal of Plant Sciences, 2 (10): 811-813. https://www.researchgate.net/publication/45946137

Simmonds, D.H. (1989). Inherent quality factor in wheat. Wheat and Wheat and Quality in Australia. Australia Wheat Board, Melbourne, PP.31-61.

Tekle Yoseph and Awoke Tadese. (2015). Effect of Cultivation Frequency on Growth, Yield and Yield Components of Bread Wheat (Triticum aestivum L.) At Selmamer, Southern Ethiopia. Pj Palgo Journal of Agriculture: V 2(4), 85-89 http://www.palgojournals.org/PJA/Index.htm

Teklu, E., Hailemariam, T. (2009). Agronomic and economic efficiency of manure and urea fertilizers use on vertisols in Ethiopian highlands. J. Agri. Sci. 8(3), 352-360

Tesfaye Geleta. (2015). Seed Rate and Sowing Method Effects on Seed Quality of Bread Wheat (Triticum aestivum L.) Varieties in Horo District, Western Ethiopia.

Troedson, R. J., R. J, Lw., K. F, Byth and G. L, Wilson. (1989). The response of field-grown wheat to saturated soil culture. Field Crop Res. 21: 171-187.

Yahia Hammad. (2015). Economics of Wheat in Egypt. 